\title{
DIY Democracy: The Direct Action Politics of U.S. Punk Collectives
}

\section{Dawson Barrett}

Somewhere between the distanced slogans and abstract calls to arms, we ... discovered through Gilman a way to give our politics some application in our actual lives.

Mike K., 924 Gilman Street

One of the ideas behind $\mathrm{ABC}$ is breaking down the barriers between bands and people and making everyone equal. There is no Us and Them.

Chris Boarts-Larson, ABC No Rio

Kurt Cobain once told an interviewer, "punk rock should mean freedom."1 The Nirvana singer was arguing that punk, as an idea, had the potential to transcend the boundaries of any particular sound or style, allowing musicians an enormous degree of artistic autonomy. But while punk music has often served as a platform for creative expression and symbolic protest, its libratory potential stems from a more fundamental source. Punk, at its core, is a form of direct action. Instead of petitioning the powerful for inclusion, the punk movement has built its own elaborate network of counter-institutions, including music venues, media, record labels, and distributors. These structures have operated most notably as cultural and economic alternatives to the corporate entertainment industry, and, as such, they should also be understood as sites of resistance to the privatizing 
agenda of neo-liberalism. For although certain elements of punk have occasionally proven marketable on a large scale, the movement itself has been an intense thirty-year struggle to maintain autonomous cultural spaces. ${ }^{2}$

When punk emerged in the mid-1970s, it quickly became a subject of interest to activists and scholars who saw in it the potential seeds of a new social movement. While the former, including both the neo-fascist National Front and the Socialist Workers Party, sought inroads for youth recruitment, the latter struggled to explain what, exactly, they thought punk was. Punk-related studies have varied widely in both method and focus, but the bulk of this research has sought to clarify punk's political nature. The most popular approaches have framed punk in the language of either a musical genre or a youth subculture. Yet despite the rationale for each, and the evidence of both, neither categorization places punk in an appropriate historical context or relates its radical ethos to the broader political Left. ${ }^{3}$

The music-centered approach to studying punk revolves around the careers of prominent bands and individuals. But while many influential musicians have helped shape punk's trajectory, a top-down perspective distorts punk's essentially horizontal structure by presenting iconic figures as movement spokespersons. Advocates of this approach assume, incorrectly, that performer/audience relationships within punk parallel the producer/consumer relationships of the corporate music industry. Widespread discussion about the co-optation of the movement has not only inflated the music industry's power but also greatly exaggerated the significance of individual bands (and hairstyles!). Punk's representation in popular culture - most notably in the late 1970s and again in the early 1990s - raises a number of interesting questions about the relationships between consumerism, identity, and resistance, but they are questions about the dynamics of popular culture, not the punk movement. The movement itself has offered no established leadership to be co-opted, either by big business or by political parties. Attempts by the entertainment industry to market punk as a commodity have transposed punk practices with style in the public view, but the effects on the movement itself have been negligible. ${ }^{4}$

Cultural analyses of punk, beginning as early as the mid-1970s with theorists such as Stuart Hall and Dick Hebdige, have generally presented a more or less grassroots perspective of the movement, for example by dissecting punk's visual representations or surveying participants. However, these studies frequently present the false premise that punk rock politics are merely symbolic, confining punk agency to only the most superficial forms of political expression. Assuming that punk resistance is limited to what James C. Scott calls the "weapons of the weak," they emphasize topics of minor significance (i.e., Mohawks and safety pins), while neglecting the movement's overtly political components. Furthermore, given punk's longevity and organizational accomplishments, comparisons between punks, mods, and teddy boys have only limited application beyond the specific context of late 1970s London. Even then, these early punk scholars 
generally fail to distinguish active participants in the movement from youth who simply look like punks. ${ }^{5}$

In the last several years, a number of activist-scholars with punk rock backgrounds have analyzed the movement through the lens of their own political radicalization. In All the Power, Mark Andersen argues that punk is often more successful in achieving what he calls the "subjective" aspects of politics, such as "personal identity, meaning, [and] purpose," than in achieving the "objective" aspects, which he defines as "actually helping to change power relations, structures, and values that uphold oppression." ${ }^{.6}$ Stephen Duncombe reaches a similar conclusion in his study of DIY culture, Notes From Underground. He maintains that because punk's rebellion is cultural rather than political, participants can "lambast the powers that be, tilt at windmills, [and] conjure up new ways of seeing, being, and doing, but never have to confront power." " In essence, Andersen and Duncombe view punk as a purely "pre-political"phenomenon-a youth culture that nurtures a healthy skepticism of authority and can serve as a steppingstone toward more formal political activism, but that is ultimately undermined by its emphasis on individual identity. ${ }^{8}$ Inspired by their own experiences, these authors' critiques help explain some of the punk movement's internal contradictions, particularly instances when countercultural individualism seems to do little more than mirror the dynamics of broader consumer society. However, I believe they undervalue the collectivist impulses that have led members of the punk movement to do significant organizational work, not only confronting dominant power structures but also proving less isolated from the rest of society than they are often presented. ${ }^{9}$

Punk's activist components are especially evident when examining the institutions and organizations that the movement has produced. In addition to highlighting the direct, participatory nature of DIY politics, an institutional focus also exposes several parallels between punk and its social movement predecessors. Most directly, punk can be linked to the New Left-inspired organization of cooperative counter-institutions that began in the late 1960s, specifically as studied by Wini Breines, Kathleen Ianello, and Joyce Rothschild. Though cooperative organization has much earlier roots in American history, the number of collectively run institutions ballooned in the post-war period from perhaps a few hundred to as many as five thousand by $1976 .{ }^{10}$ Collectives such as cooperative bookstores, coffee shops, and grocery stores, were organized according to basic New Left principles: consensus-based decision-making, voluntary participation, and relatively horizontal leadership structures. They provided spaces where those working to create a society based on participatory democracy could actually experience it. As such, they constituted a "prefigurative,"11 or direct action approach to politics - "a congruence of means and ends." ${ }^{12}$ Rather than protesting to gain access to dominant institutions, organizers instead built their own alternatives. Punk activists extended this same prefigurative organizing model, building structures that reflected their own principles rather than the dictates of 
the market. In many cases, punks even adopted the same democratic practices as their New Left predecessors. ${ }^{13}$

The politics of punk institutions effectively place the movement into a broad narrative of participatory democracy in American activism that spans from early 1960s groups like Women Strike for Peace (WSP), the Student Nonviolent Coordinating Committee (SNCC), and Students for a Democratic Society (SDS); to Women's Liberation organizations in the late 1960s and 1970s, to the global justice movement of the 1990s and 2000s. In addition to sharing a common tendency toward direct action politics, punk rock is also, by definition, a participatory movement. Punk's DIY ethos demands that participants move beyond the role of consumers and instead become actively involved by distributing self-produced zines, organizing shows (often in atypical venues, such as union halls and basements of houses), or starting their own bands (a frequently cited excerpt from an early punk zine, for example, contains a diagram of three guitar chords and features the caption, "Now Form a Band"). ${ }^{14}$ The punk movement as a whole, like these other groups, has also thrived under a largely decentralized structure - a network of local "scenes" with no central authority. In terms of structure and underlying principles, punk rock may have more links to the political New Left than the counter-culture (which could explain at least some of early punk's disdain for the remnants of hippie culture). Stuart Hall et al. argue that the distinction between the New Left and the counter-culture became blurred in the late 1960s, but this is only true when considering the most organized, most politically active counter-cultural groups. Even in these cases, the organizational practices themselves have their roots in the anarcho-New Left. In other words, punk may owe a tip of the hat to the Yippies, the Diggers, and the Up Against the Wall Motherfuckers, but less so drug guru Timothy Leary. To paraphrase Black Flag vocalist Henry Rollins, punk is about getting involved, not tuning in and dropping out. ${ }^{15}$

This paper examines the direct action politics of the American punk movement through the histories of two collectively run, all-ages punk rock venues: Berkeley, California's 924 Gilman Street and ABC No Rio, in New York City's Lower East Side. Through both their structural organization and their interactions with their respective communities, these collectives gave their members opportunities to develop their political principles, and, more importantly, to find ways to apply them. 924 Gilman and $\mathrm{ABC}$ No Rio encouraged active democratic participation, and, as a result, they cultivated skilled, empowered activists. ${ }^{16}$

\section{Internal Organization: Safety and Collective Democracy}

The introduction of punk rock shows at the ABC No Rio art gallery in 1989 and the establishment of 924 Gilman Street in 1986 occurred during a transitional period in punk history. In the late 1970s, the first wave of punk seemed to be in decline, as many of the most well-known bands of the era (the Sex Pistols, the Clash, and Blondie, for example) dissolved, signed to "major" record labels, or 
merged with the less political new wave genre. Just as punk was being declared co-opted and dead, however, a new generation of punks emerged, jolting the movement back to life with two new sub-genres, anarcho-punk and hardcore, which distanced themselves from the corporate music industry by emphasizing do-it-yourself methods. Anarcho-punk, typically associated with the English band/commune Crass, was overtly radical. Its adherents embraced communal living, feminism, vegetarianism, and grassroots anarchism, while remaining cautiously skeptical of formal ideology. Hardcore, meanwhile, was epitomized by American bands such as the Bad Brains, Black Flag, Reagan Youth, and Minor Threat, who distinguished themselves from their punk predecessors primarily by being physically and lyrically more aggressive. For the purposes of this paper, the subtle differences between the two genres are less significant than their common accomplishments. By the early eighties, this generation of punks had established their namesake as more than a musical style; they had developed a specific set of DIY values and practices and built an international network of bands, media, and activists. ${ }^{17}$

However, hardcore's pursuit of individual strength and purity quickly spiraled out of control. By the mid-1980s, a pack mentality began to take over the movement and American punk shows became increasingly dominated by violence and other expressions of machismo and intolerance. For example, while Ian MacKaye of Minor Threat had coined the term "straightedge" to describe his own personal decision to refrain from drugs and alcohol, an entire straightedge movement quickly developed - to MacKaye's horror-sometimes violently enforcing their rules on others. Such conflict was exacerbated by the lax security standards of traditional music venues, whose owners sought to maximize the admission revenue of all-ages shows in order to make up for the loss in alcohol sales. To make matters worse, club bouncers were often unpredictable, as likely to respond to non-violent situations with force as to confront actual fighting. New York City's CBGB, the venerable club where punk allegedly began a decade earlier, eventually discontinued all-ages hardcore shows altogether, but only after allowing tensions to escalate to the point that audience members were bringing guns to shows. The founding members of 924 Gilman and ABC No Rio had to confront not only an over-reliance on privately owned venues but also the apparent ambiguity of their movement's message. They did so by building volunteer-based, non-profit clubs and taking unequivocal responsibility for their patrons' security. ${ }^{18}$

ABC No Rio and 924 Gilman Street were both structured according to the same basic two-part mission: to provide a safe atmosphere by confronting violence and oppressive behavior, and to involve each member of the punk community directly, through a process of consensus-based decision-making. To accomplish the first task, each collective adopted an explicit policy against violence, racism, sexism, and homophobia, which was printed on their flyers and applied to the bands that they booked as well as audience members at their shows. 


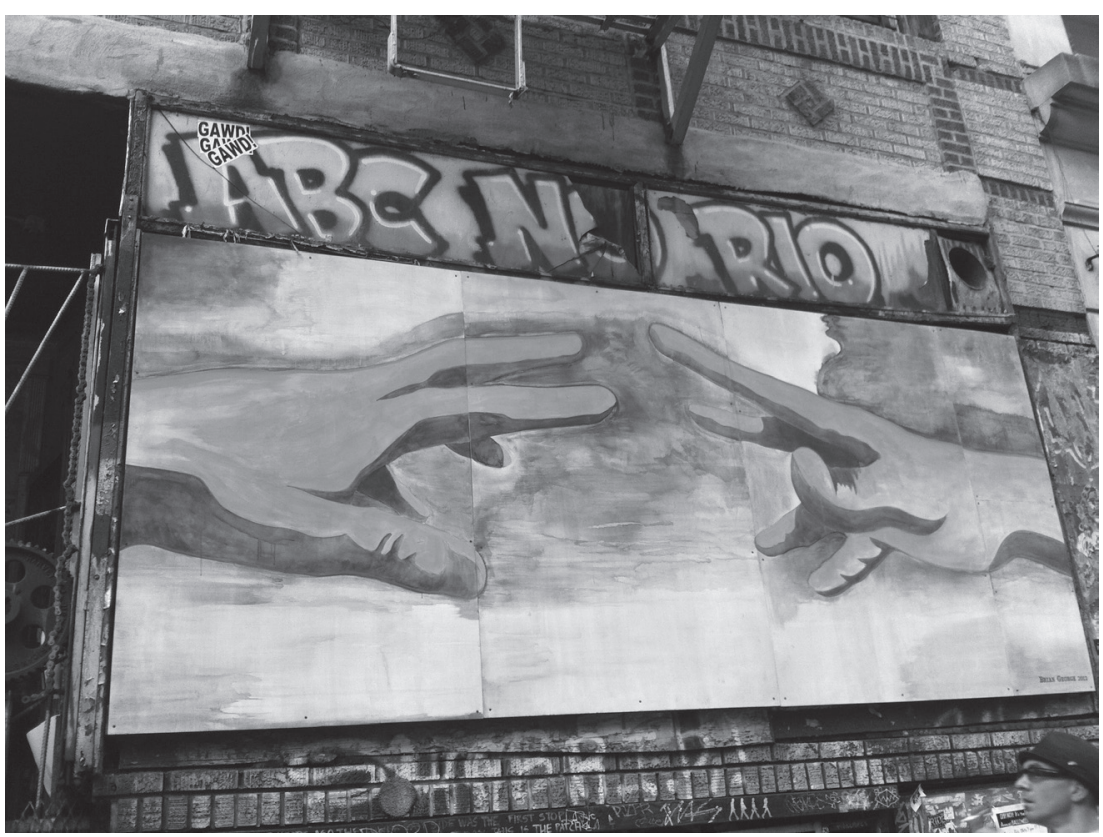

Figure 1: Entrance to ABC No Rio. New York, New York. 2012. Photograph by the author.

Though simply stating these principles ensured that each club would generally attract a less aggressive audience, collective members also experimented with a number of tactics for actually enforcing them. For example, during various periods in each club's history, collective members formed impromptu crowdmonitoring teams to identify potentially violent behavior, surround the offenders, and break into silly dances (such as conga lines) to de-escalate the situation. At Gilman, bands stopped playing if fights broke out, so that the entire audience could address the problem together. In one notable case, the singer of a performing band responded to an altercation by leaping into the crowd, microphone in hand, to interview the antagonists. After hearing the absurdity of their grievances through the sound system, the two parties quickly made amends. However, such lighthearted antics were not sufficient for every threat. ${ }^{19}$

While ABC No Rio was fairly successful at repelling the most violent elements of their scene by simply making them feel unwelcome, Gilman often attracted them. During their early years of operation, 924 Gilman's association with the well-known, outspokenly anti-racist zine Maximum RocknRoll, combined with the club's hosting of anti-racist bands and events, made it a favorite target of Bay Area neo-Nazi skinhead gangs. After experimenting with the hiring of off-duty police officers and professional security services to combat the problem, Gilman eventually trained security personnel from among their own ranks, squarely placing responsibility for their safety on their own shoulders. 


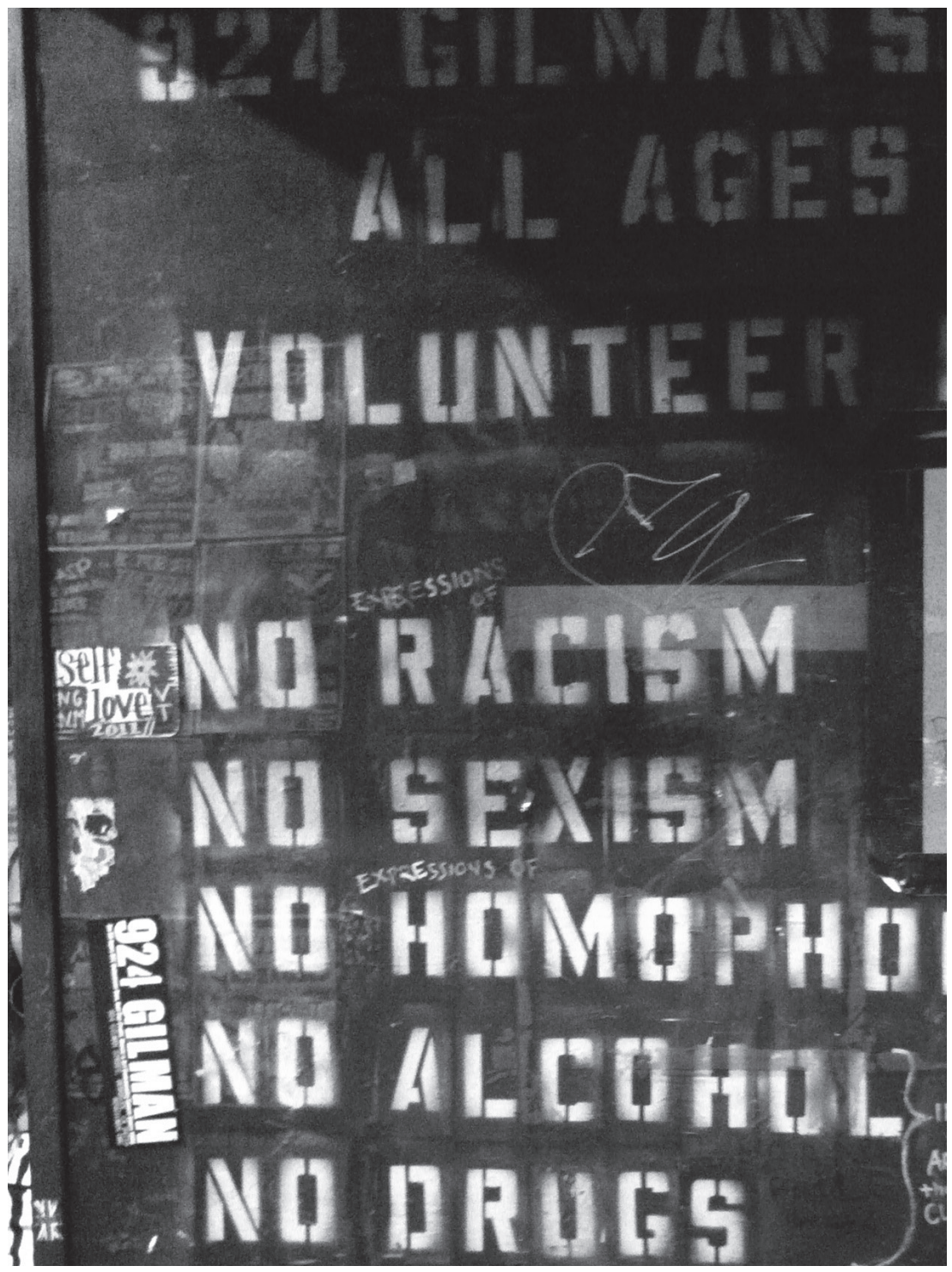

Figure 2: Entrance to 924 Gilman Street. Berkeley, California. 2012. Photograph by the author.

According to Gilman member Martin Sprouse, skinhead attacks often led to "huge confrontations" that involved "the entire crowd blocking the front door, keeping the bad guys out." ${ }^{20}$ Kamala P., another Gilman volunteer, recalls an incident when "a gang of about twenty skinheads showed up and . . . a huge fight, complete with baseball bats, chains, and chairs, erupted in front of Gilman." ${ }^{21}$ In 
these cases, words alone were not enough to discourage bigotry; the collective had to back up their principles physically, with united action. ${ }^{22}$

Enforcing a policy against sexism was more difficult, however, as offenders were not all as brazen, or as identifiable, as the neo-Nazis. In fact, they were often collective members themselves. Gilman member Michael D., for example, says that while he never had to "think twice" about confronting racism, he "went through a real mind shift on [sexism] because of Gilman." ${ }^{23}$ Although much of the responsibility for challenging sexist behavior ultimately fell to the women of the club, naming sex-based oppression as a collective problem helped create a negotiable, if not entirely "free," space. Volunteer Lauren L., for example, says that she is

comfortable enough [at Gilman] to speak up when guys say stupid shit to me or other women. I don't have to accept that kind of stuff. I know that the other people there will back me up. ${ }^{24}$

In addition to speaking out, women at Gilman also used several other methods to confront chauvinist attitudes. At one point, women hung giant banners on the inner walls that read, "She plays really good for a girl' (think about what you just said)" and "“Hey, Baby, hold my jacket so I can go in the pit' FUCK YOU!" 25 Gilman women also organized events that celebrated women in punk, hosted touring punk-feminist Riot Grrrl bands, coordinated a regularly meeting women's caucus, and, perhaps most importantly, started bands of their own. Because of the collective's horizontal structure, women also performed traditionally male jobs, serving as club security guards, sound engineers, booking agents, and officers. Gilman did not deliver a utopian model for gender equality; the club did, however, provide a supportive environment where women could assert their own agency. Volunteer Athena K., for example, credits her experiences at Gilman for giving her "a sense of self-respect about being biracial and . . a young woman," and several other women offer similar accounts of empowerment. ${ }^{26}$

Perhaps because Mike Bromberg, who booked the first ABC No Rio punk shows, had the reputation of being the first openly gay punk in New York's notoriously intolerant hardcore scene, issues surrounding homophobia seemingly played a larger role there than at Gilman (though the neo-Nazis, of course, represented the antithesis of every plank in the club's platform). Most bands, and individuals, were specifically drawn to ABC No Rio because they supported the venue's policies, but those who were excluded periodically lashed out, as in the case of a particularly inflammatory November 1990 letter to the editors of Maximum RocknRoll. In response to previous comments by ABC No Rio-associated bands, the author of the letter writes:

I'll tell you what's wrong with girls ... they're ... weak and it's easy to kick their ass ... I've talked to people who go to ABC NO RIO's and it seems a new trend to be anti-homophobic 
because some faggot runs the club, yes faggot. I was brought up to refer to those people as such, and I'm not going to change my whole vocabulary for the sake of some stupid trend... Fuck off and learn what 'HARD'core is all about and stop being brainwashed by [Maximum RocknRoll]. ${ }^{27}$

The author not only associates ABC No Rio and Maximum RocknRoll (which provided the initial funds for 924 Gilman) with feminist and anti-homophobic ideas, he specifically identifies this "trend" as a departure from what he believes hardcore is "all about." In another case, a band wishing to play at ABC No Rio submitted a demo that featured a song entitled, "The Faggot Stomp." When confronted by Bromberg, however, the band apologized and said that they no longer espoused such beliefs. Satisfied with their response, Bromberg eventually let them play at the club. Although the attempts of the 924 Gilman and ABC No Rio punks to create relatively safe spaces were not unchallenged or without missteps, they were fairly successful overall, primarily because the collectives' members were persistent and quick to try creative approaches to solving their problems. This tenacity and flexibility stemmed directly from the democratic structures that each adopted. ${ }^{28}$

Like many of their New Left predecessors, 924 Gilman and ABC No Rio operated on a system of modified consensus. Day-to-day decisions were made by elected officers, but the clubs' major decisions required unanimous approval at monthly meetings, and every member's vote was equal. As ABC No Rio member Tucker explains,

Anyone is welcome to come to our meetings and have input on what we do, though only collective members have voting rights (which are obtained by volunteering regularly). Also, in an effort to increase the openness of the collective and what we're doing, each of the bookers hold booking hours which are open to anyone to attend. . . If we have a problem with any person or band then we give them the opportunity to speak at a collective meeting before any decisions are made about them (bannings, etc.) ... Any decision we make is open for discussion and not made by some ultimate authority. ${ }^{29}$

924 Gilman employed similar practices, but the collective also required that patrons pay an annual membership fee with admission to their events. Doing so made all audience members accountable to the club's policies and gave them an equal stake in the club's future. The significance of the access that Gilman provided its members is not lost on volunteer Mike Goodbar, who said,

At meetings, 14-year-olds have an opportunity to deal with issues sometimes as complex as those faced by 46 -year-olds 
involved with big business corporations. In the regular world a person would have to have ... access to the right job or [a privileged] situation that would provide the same experiences that Gilman does to anyone who's interested. ${ }^{30}$

The Gilman collective also experimented with a number of innovative methods to increase participation in the democratic process. Early in the club's history, for example, the collective installed a suggestion box and read its contents aloud over the microphone during shows. They also tried a short-lived policy of leaving the microphone on in between bands, allowing audience members the opportunity to question performers about their lyrical content. Gilman's inner walls likewise served as a canvass for free expression and ongoing dialogue. Though not all of these policies were successful, they illustrate the collective's desire to involve as many people as possible in the maintenance of the club. ${ }^{31}$

Despite the clarity of their goals, however, both ABC No Rio and 924 Gilman experienced pitfalls and growing pains as they attempted to establish democratic structures. During Gilman's early years, Tim Yohannon of Maximum RocknRoll often held informal veto power over the collective's decisions, due to the magazine's large financial investment. Yohannon eventually became frustrated with what he interpreted as a lack of initiative among the membership and withdrew from the project. The remaining members opted to continue running the club, however, and Yohannon offered them the building's lease and sound system. During this transition, the collective decided to officially incorporate the venue as a non-profit, which limited their financial risk but also created an undesired de facto hierarchy by requiring the appointment of legally adult officers. ${ }^{32}$

$\mathrm{ABC}$ No Rio faced similar challenges. Although the art gallery itself had been run collectively since 1980 , the initial punk shows in the late 1980s and early 1990s were organized in a less formal manner typical of DIY punk. Individuals like Mike Bromberg booked the shows, but band members and friends contributed by taking money at the door, preventing fights, and cleaning up afterward. Within a few years, the ABC No Rio punks began organizing their efforts in a much more structured fashion, which subsequently allowed them to take a greater stake in the maintenance of the building. However, this transition presented the group with several obstacles. Initial efforts to democratize booking practices, for example, resulted in a free-for-all that failed to establish a mechanism for ensuring that every show had the appropriate bands, volunteers, and promotion. Eventually, the collective learned from these mistakes and developed practices that were both effective and in line with their democratic values. ${ }^{33}$

Although 924 Gilman and $\mathrm{ABC}$ No Rio each benefited from the initial involvement of members with extensive organizational backgrounds, most collective members had no previous experience with activism. However, because they encouraged active participation, the clubs attracted and involved new members and developed through a process of trial and error. They allowed room for democratic experimentation that not only empowered their members indi- 
vidually but also taught them how to resolve conflict collectively. The internal organizing models that Gilman and $\mathrm{ABC}$ No Rio adopted led their members to learn communication and problem-solving skills, which they ultimately used to confront external crises, as well.

\section{External Organization: Conflict and Campaigns}

During the 1990s, altercations with neighbors and government officials nearly forced 924 Gilman to close on three separate occasions. The first major conflict began in 1991, when the collective requested a change to their city permit. At the behest of Tim Yohannon, the club's original 1986 charter had contained a clause that prohibited advertising for Gilman events. Yohannon had hoped that the punk community would support the club regardless of which bands were playing, but the policy had never been successful. As part of the permit modification process, the Berkeley Zoning Board sought input from local police, who reported that Gilman's control over its patrons was inadequate, leading to underage drinking, loitering, and vandalism. After reviewing these complaints, the board not only rejected the collective's request but also threatened to revoke the permit altogether. They eventually granted the club six months in which to make the necessary improvements before facing a final judgment. ${ }^{34}$

If the Gilman punks had previously taken their status in their community for granted, the permit crisis awakened them to their responsibilities. In response to the board's ruling, the collective quickly launched a petition drive and began acquiring letters of support from former workers, patrons' parents, and other members of the Berkeley community. Volunteers also went door-to-door to solicit suggestions and support from the club's neighbors. Throughout the process, Gilman members worked closely with the police department and the city government. In January 1992, for example, representatives of the club met with local police through the city's dispute resolution service in order to build a more constructive working relationship. When the venue's permit again appeared on the Zoning Board's agenda, more than one hundred Gilman supporters attended the meeting. The overwhelming support for the club pressed the board to grant the requested permit changes, with stipulations that the collective provide additional outdoor trash cans and continue to improve their internal security. ${ }^{35}$

Gilman's second major crisis began in 1995, when the Pyramid Brewing Company announced its intention to open a brewpub directly across the street from the club. In addition to recognizing problems inherent to locating a drinking establishment near an all-ages venue, collective members were also worried that the arrival of an upscale establishment would drive up property costs and eventually force them out of the neighborhood. To voice these concerns, Gilman representatives attended Pyramid's preliminary permit hearing, and three collective members accepted the brewing company's invitation to visit their Seattle, Washington headquarters. The collective also issued a series of successful press 
announcements, conducted an outreach campaign to their other neighbors, and filed a formal petition with the Berkeley Zoning Board. ${ }^{36}$

When the brewpub's permit came before the board, dozens of Gilman supporters spoke on the club's behalf, and one zoning officer later described the presentation as "one of the most professional" he had seen. ${ }^{37}$ Although the board approved Pyramid's permit, they also addressed many of the collective's concerns by requiring that the brewing company pay for a new traffic light, hire security guards to contain bar patrons, and meet regularly with Gilman members to resolve disputes. Gilman's interaction with Pyramid, while serious in its potential ramifications, was not entirely antagonistic. Pyramid responded to the collective's concerns with seemingly genuine concern, and a representative of the brewpub even wrote a letter of support for Gilman during its next major conflict. ${ }^{38}$

Gilman's third altercation of the decade was its most hostile. In October 1998, DiCon Fiber Optics, a neighboring business, filed a grievance with the city that the club's patrons were responsible for an increasing amount of vandalism, graffiti, and litter. The company's complaints, which included the sensational claim that Gilman patrons had attacked the company's trees with machetes, were probably overblown. Gilman cleanup crews already tended to neighborhood trash and vandalism, and, according to Gilman volunteer John H., "Eighth Street was a sort of no-man's-land on which many users dumped trash. Gilman [unfairly] received the blame for much of it." ${ }^{\prime 39}$ Nonetheless, the company's threat to re-locate four hundred high-paying jobs was enough to persuade the city to intervene. In December, Berkeley police set up video and still camera surveillance on the club in order to catch vandals in the act, though they were apparently unsuccessful. ${ }^{40}$

During the ensuing months, Gilman members canvassed the neighborhood for support and gathered several thousand signatures on an online petition. DiCon, however, continually refused the club's offer to pursue mediation. Eventually, at the city's behest, representatives from both sides met with police and city planning officials to draft a memorandum of understanding. The collective agreed to increase its attention to neighborhood graffiti, but DiCon stopped meeting with the club's representatives and moved out of the neighborhood soon afterward. As in their two previous conflicts, Gilman was able to work through formal government channels from a position of relative strength, but this was only because of the collective's ability to gain the support of their neighbors, rather than alienating them. The default loyalties of city officials and the police were to the concerns of businesses. ${ }^{41}$

$\mathrm{ABC}$ No Rio also faced major crises during this period, but their circumstances ultimately required a more aggressive response. The $\mathrm{ABC}$ No Rio art gallery had been enmeshed in the housing politics of New York's Lower East Side since its 1980 founding. In fact, its lease was a concession from the city following a dispute over an illegal art exhibit that focused on gentrification in the neighborhood. The punk contingent that took over the space a decade later inherited an institutional history of conflict with the city government and solidar- 
ity with the neighborhood's homeless and squatter populations. Throughout the nineties, these relationships continued to define ABC No Rio's position in its community and played a central role in the collective's development. ${ }^{42}$

The punk contingent arrived at $\mathrm{ABC}$ No Rio during a period of escalation in the Lower East Side's housing conflict. In the summer of 1988, the city attempted to enforce a curfew on nearby Tompkins Square Park, which had become a residence for the neighborhood's homeless community. Over the next several months, a series of protests were held to contest the city's actions, which also included the eviction of squatters in nearby buildings. Police responded to the protests with force, resulting in arrests and injuries; one specific protest generated over one hundred complaints of police brutality. The city pressed on, however, and by June 1991, the two hundred homeless residents of the park had been evicted, and the area was indefinitely cordoned off for renovations. Though ABC No Rio was not directly involved in this dispute, the gallery did host benefits for local evictees and screened raw footage from the Tompkins Square riots. Meanwhile, the collective's relationship with the city government continued to be as adversarial as it had been during its founding. The city proved to be a negligent, and often hostile, landlord, and the collective responded by filing several lawsuits and engaging in a five-year rent strike that was resolved, only unofficially, in 1993. Two years later, the neighborhood's housing conflict again intensified, this time with more direct effects for $\mathrm{ABC}$ No Rio. ${ }^{43}$

In May 1995, hundreds of New York City riot police, complete with an armored vehicle, arrived in the Lower East Side to evict squatters from buildings on East $13^{\text {th }}$ Street. The thirty-one squatters inside were expecting the eviction and had barricaded the doors and stairways of their buildings. Although the squatters were forced out within a few hours, several of them re-occupied one of the buildings on the Fourth of July, while police forces were engaged with crowds at a nearby fireworks presentation. Police again cleared the squat and arrested nearly twenty people on charges ranging from disorderly conduct to attempted murder. The circumstances of these evictions were particularly controversial, as the New York State Supreme Court had previously ruled in the squatters' favor. ${ }^{44}$

In this context of overt hostility, overwhelming police force, and bad faith negotiations, the $\mathrm{ABC}$ No Rio collective became embroiled in their own eviction battle. In October 1994, the city stopped depositing the gallery's rent checks, and over the next several months, officials moved to evict the collective and formally "dispose" of the building. Despite the collective's many offers to purchase the building, the city instead made arrangements to sell it to a non-profit housing organization, Asian Americans for Equality (AAFE). Hesitant to battle another non-profit group, $\mathrm{ABC}$ No Rio members attempted to negotiate for partial use of the space, but AAFE's proposal required that $\mathrm{ABC}$ No Rio pay double the market rate for rent, and the two parties were unable resolve a temporary re-location for the gallery during proposed renovations. ${ }^{45}$

Talks between the groups quickly broke down, and the city moved to bypass normal public hearings by declaring the space an "Urban Development Action 
Area Project" (UDAAP). ABC No Rio responded by taking their case to the media, publicly vowing to fight for the gallery through "the courts...outreach, protest ... public support, and ... physical defense of the building." ${ }^{.46}$ Squatters, meanwhile, moved into the building in order to provide a last line of defense against eviction. ${ }^{47}$

In November 1995, ABC No Rio representatives testified at a hearing of the city's Permits, Dispositions, and Concessions Subcommittee. They explained the collective's role in New York's alternative arts scene, their attempts, through Food Not Bombs, to feed the neighborhood's hungry each week, and their efforts to host children's arts classes. They also related their long history with the city, including the many offers to purchase the building. The council nonetheless voted unanimously to expedite the transfer of the building, and from late 1995 through 1996, the collective worked to publicize their struggle and prevent their ousting through legal channels. In April 1996, they won an important, though temporary, victory when their eviction proceedings were dismissed - for the third time. The collective also filed a lawsuit of their own, claiming that the city's actions were politically motivated. In preparation for yet another eviction hearing in October, $\mathrm{ABC}$ No Rio, along with several other threatened arts organizations, held a fundraising rally at the Metropolitan Museum of Art. ${ }^{48}$

By December 1996, the gallery's situation had become desperate. That month, a judge suspended eviction proceedings, but only until city officials restored utilities to the building, which they had illegally disconnected. The stay was only expected to last for a few months, so the collective began 1997 by escalating their tactics. In January, collective members organized two public actions that targeted AAFE. In the first, ABC No Rio sympathizers plastered the group's headquarters with posters reading "Greed," "Profiteering," and "Corruption." Two dozen protestors rang bells and played drums while others loudly decried the group's role in eviction proceedings. Later that month, collective members again targeted the AAFE office, chaining themselves to desks and windows and demanding that the eviction process be stopped; five of the protestors were arrested. The collective then shifted their focus to the housing department with a sit-in at the agency's office. Following the demonstration, outgoing commissioner Liliam Barrios-Paoli invited ABC No Rio representatives to a meeting, at which she offered to sell the building to the collective for $\$ 1$. In exchange, the gallery was required to expel its squatters and raise $\$ 100,000$ for renovations. The collective accepted the offer and began developing formal plans for building restoration and fundraising. ${ }^{49}$

Over the next several years, city officials repeatedly changed the amount of money that they expected the group to raise. By October 2004, the collective had raised nearly $\$ 300,000$ (primarily through small donations), and the long process of transferring ownership of the building began. In June 2006, the sale was finalized, after more than twenty years of fighting the city for the building. However, the collective soon realized that simple renovations would be insufficient for the dilapidated space, and they instead began pursuing a more ambi- 
tious, two million dollar tear down and rebuild. Three years later, almost to the day, the collective announced an interesting twist to their historically volatile relationship with the city government. In June 2009, city officials granted the now internationally renowned $\mathrm{ABC}$ No Rio $\$ 1,650,000$ in municipal funding for their rebuilding project. ${ }^{50}$

During their eviction battle, the ABC No Rio collective used a variety of tactics to maintain control of the building. Through official channels, the gallery engaged local officials, ultimately extending its month-to-month lease for over two years. As the conflict escalated, collective members also engaged in civil disobedience in the form of sit-ins as well as the physical occupation of their building. ABC No Rio's biggest asset, however, was its ability to gather public support through extensive, positive press coverage in both alternative and mainstream media. Like their counterparts at 924 Gilman, ABC No Rio members refused to be isolated in their struggles, and they used every tool available to them, not just the most inflammatory. They were inherently radical spaces, and their survival depended on effective, not just symbolic, strategies and tactics. ${ }^{51}$

\section{Conclusion}

924 Gilman Street and ABC No Rio were founded during a period of conservative political dominance in the United States. The punks who organized these venues did so to challenge parallel reactionary elements in their own communities and to reclaim the punk movement from a politically nebulous trajectory. They responded to the machismo of 1980s hardcore with clear, outspoken positions against violence and oppression, and they worked collectively to find viable methods for enforcing them. Undoubtedly, the policies that they developed had limitations. The collectives' definitions of racism, sexism, and homophobia, for example, struggled to address more than their most blatant forms. Nonetheless, the principles that the Gilman and ABC No Rio punks outlined were not just lip service, they backed up their words with actions. While right-wing pundits spent the 1980s and early 1990s assuaging white guilt and re-defining anti-racism as a case of political correctness run amuck, punks at 924 Gilman were fighting off neo-Nazi skinheads. And while New York City Mayor Rudy Guiliani devoted his administration to a general assault on civil liberties, the arts, and social services, punks at $\mathrm{ABC}$ No Rio spent the mid-1990s challenging the legitimacy of the city's housing department. Against the rise of neo-liberalism in the 1970s and 1980s, which aimed to destroy the very idea of the commons, punk rock sought to carve out a space that was closed to the market and controlled by the community that used it.

The punk movement's cultural form has led many scholars to assume that its politics are stylistic and thus of a purely symbolic nature. These surface-level, and ultimately condescending, approaches to studying punk may be appropriate when teenagers limit their rebellion to spiking their hair or listening to loud music, but they have very little to offer when youth respond to their environment with 
proactive organization. Although Gilman and $\mathrm{ABC}$ No Rio were ostensibly punk rock venues, they also served as battlegrounds for a variety of Leftist causes. Like their counterparts in the cooperatives movement of the late 1960s and 1970s, the Gilman and $\mathrm{ABC}$ No Rio collectives confronted dominant institutions by organizing local alternatives that reflected their values. The methods they used to build these institutions also borrowed heavily from the democratic movements of that period. Punks may be atypical community organizers, but they are activists nonetheless. Their movement, warts and all, needs to be included in the same conversation as these other groups.

924 Gilman and $\mathrm{ABC}$ No Rio are the most well-known youth-run, all-ages punk rock venues in the United States, due to their longevity, as well as their progeny. Gilman helped launch the careers of internationally known bands such as Operation Ivy, Neurosis, Jawbreaker, Samiam, and most famously, Green Day. ABC No Rio, meanwhile, was a home base for Born Against, Ted Leo, and Chris Boarts-Larson's zine Slug + Lettuce - as well as many non-punk artists. The spaces are not otherwise unique within American punk, however. Similarly structured venues have been organized with varying degrees of success throughout the country, including the Vera Project in Seattle, Washington; 1919 Hemphill in Fort Worth, Texas; Solidarity Books in Indianapolis, Indiana; the BRYCC House in Louisville, Kentucky; and the Mr. Roboto Project in Wilkinsburg, Pennsylvania. Punk counter-institutions have also included a number of cooperative record labels and zines, most notably Maximum RocknRoll and Profane Existence. Members of any of these groups would have likely confronted organizational challenges similar to those faced by the Gilman and $\mathrm{ABC}$ No Rio collectives, but even less structured DIY punk ventures necessitate the development of basic organizing skills, such as designing and distributing flyers, monitoring crowds, and negotiating with police and neighbors. ${ }^{52}$

Perhaps because these skills have been so essential to its development, the punk movement has played a prominent though not exclusive role in the global fight to maintain autonomous cultural spaces. Just as ABC No Rio's eviction battle represented only one portion of a much larger struggle over housing and public space in New York City, the conflicts faced by the Gilman and ABC No Rio collectives more generally were also part of a larger trend. Because DIY punk is, by design, not catered toward profitability, its institutions have often been forced to the economic margins, locating in low rent neighborhoods or abandoned warehouses. Renewed capitalist interest in these areas has led to major clashes, with state and private interests on one side and the often awkward alliance of punks and neighborhood residents on the other.

Furthermore, the radical political nature of punk rock spaces has not escaped the notice of police. While the surveillance of 924 Gilman Street in the late 1990s was relatively innocuous, dozens of other alternative arts spaces have experienced similar and often more repressive interference. For example, Indianapolis's Solidarity Books was closed in 2003, ostensibly for a fire code violation, after weeks of surveillance and a joint raid by the local police, the bomb squad, and 
the federal Bureau of Alcohol, Tobacco, Firearms, and Explosives. Richmond, California's Burnt Ramen and Los Angeles's The Smell suffered similar fates the same year. Outside the United States, clashes between police and youth have been even more pronounced over spaces such as the Ungdomshuset in Copenhagen, Denmark; Metelkova in Ljubljana, Slovenia; Fabryka in Warsaw, Poland; and Köpi in Berlin, Germany-all of which have also served as punk rock venues. And while conflict with police forces is not in itself particularly important, the basis for this fight is. Punk rock is an ongoing struggle for the freedom to construct culture, and as such, it is one branch of a much broader movement for democratic participation. ${ }^{53}$

\section{Notes}

1. Nirvana and Kevin Kerslake, dir., Nirvana: Live! Tonight! Sold Out!! VHS (Los Angeles: Geffen Records, 1994). In both a nod to Nirvana's impact and a reflection on the state of the movement itself, Sterling, Virginia-based screamo punk legends opened their 2001 album Document \#8 with a sample of Cobain's quote. Pg. 99, Document \#8 LP/CD/Tape (Richmond: Robotic Empire Records, 2001).

2. Though definitions of "direct action" vary widely, David Graeber, in Direct Action: An Ethnography, offers several, including a useful description by Rob Sparrow: "direct action aims to achieve our goals through our own activity rather than . . . concede our power to existing institutions." David Graeber, Direct Action: An Ethnography (Oakland, CA: AK Press, 2009), 201-11.

3. Anouk Fontaine and Don Letts, dir., Punk: Attitude, DVD, (Burbank: Capital Entertainment, 2005); Roger Sabin, “I Won't Let That Dago By': Rethinking Punk Rock and Racism," in Punk Rock, So What?, ed. Roger Sabin (London: Routledge, 1999), 199-218; Javier Santiago-Lucerna, "'Frances Farmer Will Have Her Revenge on Seattle:' Pan-Capitalism and Alternative Rock," in Youth Culture: Identity in a Postmodern World, ed. Jonathan S. Epstein (Malden, MA: Blackwell Publishers, 1998), 189-94

4. This genre includes countless biographies and documentaries. See, for example, John Lydon, Rotten: No Irish, No Blacks, No Dogs (New York: Picador USA, 1994); Dee Dee Ramone et al., Lobotomy: Surviving the Ramones (Cambridge, MA: Da Capo Press, 2000); David C. Thomas, dir., MC5: A True Testimonial, DVD, (Future/Now Films, 2002). It also includes music journalism, such as Gina Arnold, Route 666: On the Road to Nirvana (New York: St. Martin's Press, 1993); Matt Diehl, My So-Called Punk: Green Day, Fall Out Boy, the Distillers, Bad Religion-How Neo-Punk Stage-Dived into the Mainstream (New York: St. Martin's Griffin, 2007).

5. Dick Hebdige, Subculture: The Meaning of Style (London: Routledge, 1979); John Clarke, Stuart Hall, Tony Jefferson, and Brian Roberts, "Subcultures, Cultures, and Class: A Theoretical Overview," in Resistance Through Rituals: Youth Cultures in Post-War Britain, ed. Stuart Hall and Tony Jefferson (London: Hutchinson University, 1976), 9-79; Curry Malott and Milagros Pena, Punk Rockers'Revolution: A Pedagogy of Race, Class, and Gender (New York: Peter Lang Publishing, Inc., 2004); Ross Haenfler, Straight Edge: Hardcore Punk, Clean-Living Youth, and Social Change (New Brunswick: Rutgers University Press, 2006); Lauraine Leblanc, Pretty in Punk: Girls'Gender Resistance in a Boys 'Subculture (New Brunswick: Rutgers University Press, 1999); Kristen Schilt, " "Riot Grrrl Is . . .': The Contestation over Meaning in a Music Scene," in Music Scenes: Local, Translocal, and Virtual, ed. Andy Bennett and Richard A. Peterson (Nashville: Vanderbilt University Press, 2004), 115-30; Jason Middleton, "D.C. Punk and the Production of Authenticity," in Rock Over the Edge: Transformations in Popular Music Culture, ed. Roger Beebe, et al. (Durham: Duke University Press, 2002), 335-56. While Scott's framework can be applied to many elements of punk rock activism, it is important to heed his many warnings not to romanticize the weapons of the weak or to assume that every action is necessarily a form of resistance. James C. Scott, Weapons of the Weak: Everyday Forms of Peasant Resistance (New Haven: Yale University Press, 1986). 2004), 22.

6. Mark Andersen, All the Power: Revolution without Illusion (Chicago: Punk Planet Books,

7. Stephen Duncombe, Notes From Underground: Zines and the Politics of Alternative Culture (New York: Verso, 1997), 193.

8. Duncombe, Notes From Underground, 188-193.

9. Andy Cornell, in Letters From Young Activists, articulates a similar criticism of punk as the movement's elevation of "activism" (self-expression) over "organizing" (long-term mobilization of people toward a specific end). Although I argue that 924 Gilman Street and ABC No Rio offer concrete examples of actual organizing within punk, for purposes of clarity I will not adopt Cornell's 


\section{Dawson Barrett}

definitions in this paper. Andy Cornell, "Dear Punk Rock Activism," in Letters to Young Activists, ed. Dan Berger, Chesa Boudin, and Kenyon Farrow (New York: Nation Books, 2005), 69-75.

10. Kathleen Ianello, Decisions without Hierarchy: Feminist Interventions in Organization Theory and Practice (New York: Routledge, 1992), 31.

11. Wini Breines, Community and Organization in the New Left, 1962-1968: The Great Refusal (New Brunswick: Rutgers University Press, 1989), 53.

12. Joyce P. Rothschild and J. Allen Whitt, The Cooperative Workplace: Potentials and Dilemmas of Organizational Democracy and Participation (Cambridge: Cambridge University Press, 1986), 17

13. An institutional perspective may also help clarify the relationship between punk and the broader Left by applying the model outlined by Sara Evans and Harry Boyte in Free Spaces. Evans and Boyte argue that participatory settings can become "breeding grounds for democratic change" by providing an activist/organizer skill set that propels further political movements. For example, the Civil Rights movement of the early 1960s relied on a large base of organizers, many of whom were inadvertently trained through participation in local churches. Not only did these churches provide a venue for open discourse, active congregation members also learned basic organizing skills, such as how to run meetings, recruit new members, and hold fundraisers. By this same pattern, many second-wave feminists cut their teeth in groups like SDS and SNCC. Evans' and Boyte's interest in autonomous space is also shared by several other authors. Following Stuart Hall et al., who present a street corner as an example of youth liberated space, Andersen and Duncombe both argue that the punk community can serves as a free space for youth. See also Hakim Bey's similar concept, the "Temporary Autonomous Zone." Evans and Boyte differ from these other authors, however, with their emphasis on the skills that participants gain in these spaces. The case studies in this paper, like churches and social justice groups, expose participants to more sophisticated organizational structures and methods than that of a street corner. Sara M. Evans and Harry Chatten Boyte, Free Spaces: The Sources of Democratic Change in America (New York: Harper \& Row, 1986), 42-43, 61, 102-03, 187; Hall et al., "Subcultures, Cultures, and Class: A Theoretical Overview," 43-47; Hakim Bey, T.A.Z.: The Temporary Autonomous Zone, Ontological Anarchy, Poetic Terrorism (Brooklyn: Autonomedia, 1991).

14. Ryan Moore, “Friends Don’t Let Friends Listen to Corporate Rock: Punk as a Field of Cultural Production," Journal of Contemporary Ethnography 36, no. 4 (August 2007), 446; Duncombe, Notes From Underground, 118-21.

15. The connections between SNCC, SDS, and the Women's Liberation movement are outlined by Sara M. Evans and extended to the Global Justice movement by Francesca Polletta. Sara M. Evans, Personal Politics: The Roots of Women's Liberation in the Civil Rights Movement and the New Left (New York: Alfred A. Knopf, 1979); Francesca Polletta, Freedom is an Endless Meeting: Democracy in American Social Movements (Chicago: University of Chicago Press, 2002). Hall et al, "Subcultures, Cultures, and Class: A Theoretical Overview," 61; Andersen, All the Power, 114.

16. Although there have been many similarly structured punk institutions in the United States, 924 Gilman Street and ABC No Rio were selected for this study both because their reputations have made them internationally influential and because the collectives themselves have taken an interest in documenting their own histories. In 2004, former Gilman volunteer Brian Edge published a compilation of Gilman's internal documents, press clipping about the venue, and seventy-eight essays by former Gilman workers. Edge's collection, 924 Gilman: The Story So Far . . . , is arranged in approximate chronological order and divided according to the club's major conflicts with the local government and neighboring businesses. The collection is effectively a Gilman archive, and Edge's editing is limited to replacing collective members' last names with initials, in order to protect their privacy. The ABC No Rio collective, meanwhile, has used their web page to store several news articles and internal documents from various periods in their history. 924 Gilman: The Story So Far , ed. Brian Edge (San Francisco: Maximum RocknRoll, 2004); ABC No Rio, "ABC No Rio History," http://www.abcnorio.org/about/history/history.html (accessed July 3, 2007). ABC No Rio has also published a book about its early history as an art gallery, though that specific topic is beyond my focus. ABC No Rio Dinero: The Story of a Lower East Side Art Gallery, ed. Alan Moore and Marc Miller (New York: ABC No Rio with Collaborative Projects, 1985). Kamala Parks, Branwyn Bigglestone, Chris Boarts Larson, and Esneider also shared their memories with the author, and he is deeply grateful for their time and assistance.

17. Among Crass' many hijinks was the anonymous release of the "Thatchergate" tape, a bogus recording of a conversation between Ronald Reagan and Margaret Thatcher in which the former threatens to bomb Europe and the latter claims responsibility for deliberately escalating the Falklands War. Though eventually linked back to the band, initial reports linked the tape to the KGB. George McKay, Senseless Acts of Beauty: Cultures of Resistance Since the Sixties (London: Verso, 1996), 75, 80-82, 86; Richard Cross, “"The Hippies Now Wear Black': Crass and the anarcho-punk movement, 1977-1984," Socialist History 26 (2004), 25, 32, 34, 37-38; Fontaine et al., dir., Punk: Attitude; Steven Blush and Paul Rachmen, dir., American Hardcore, DVD (Culver City, CA: Sony Pictures Home Entertainment, 2007); Tim Gosling, "Not For Sale': The Underground Network of Anarcho-Punk," in Music Scenes: Local, Translocal, and Virtual, ed. Bennett and Peterson, 170-74. 
18. Leblanc, Pretty in Punk, 48-54; Blush and Rachmen, dir. American Hardcore; "Jake Filth," in 924 Gilman, 43.

19. "Mike K.," in 924 Gilman, 106; "Devon M.," in 924 Gilman, 47; Brian Edge, in 924 Gilman, 67; Vicki Law, Enter the Nineties: ABC No Rio Poets, Punks, Politics (2005), 23.

20. Martin Sprouse, in 924 Gilman, 14.

21. "Kamala P.," in 924 Gilman, 40.

22. Jonathan Denlinger, in 924 Gilman, 83, 86; Tim Yohannon, in 924 Gilman, 11; Ben S., in 924 Gilman, 156

23. "Michael D.," in 924 Gilman, 133.

24. "Lauren L., in 924 Gilman, 253.

25. Photographs by "Susan S.," in 924 Gilman, 285.

26. "Athena K.," in 924 Gilman, 120; Rachel Siebert, in 924 Gilman, 281-82, 284-85; Jane G.," in 924 Gilman, 19; "Celia S.," in 924 Gilman, 217; "Adrienne D.," in 924 Gilman, 27; "Lauren L.," in 924 Gilman, 253. For more on the Riot Grrrl movement, see Kristen Schilt, "'Riot Grrrl Is...': The Contestation over Meaning in a Music Scene," 115-30; Kerri Koch, dir., Don't Need You, DVD (Urban Cowgirl Productions, 2006); Ryan Moore, "Friends Don't Let Friends Listen to Corporate Rock," 465-66; and Mark Andersen and Mark Jenkins, Dance of Days: Two Decades of Punk in the Nation's Capital (New York: Akashic Books, 2003).

27. "Anthony S," letter to the editors, Maximum RocknRoll 90 (November 1990).

28. Law, Enter the Nineties, 7, 29; Jim Testa, "Interview with Mike Bullshit," Jersey Beat 39, (1990); Chris Boarts-Larson, e-mail message to author, September 9, 2007; Esneider, e-mail message to author, August 20, 2007.

29. Jim Testa, "The Hardcore Matinees Today: Still DIY After All These Years," Jersey Beat 77 (2005).

30. Mike Goodbar, in 924 Gilman, 181 .

31. "Clayton M.", in 924 Gilman, 234; Kerith Pickett, in 924 Gilman, 49; Mike Goodbar, in 924 Gilman, 181; Tim Yohannon, in 924 Gilman, 9; Brian Edge, in 924 Gilman, 66.

32. Kerith Pickett, in 924 Gilman, 49; Tim Yohannon, in 924 Gilman, 7; "Jonathan D.," in 924 Gilman, 88-89.

33. Law, Enter the Nineties, 9; Testa, "Interview with Mike Bullshit"; Testa, "ABC No Rio: The Rise and Fall"; Chris Boarts, Slug + Lettuce 32 (November 1993); David Powell, letter to the editor, Jersey Beat 58 (Fall 1996).

34. Tim Yohannon, 924 Gilman, 8; “John H.," in 924 Gilman, 168; 924 Gilman, 159.

35. Michael Diehl, in 924 Gilman, 133; 924 Gilman, 158-64.

36. "John H.," in 924 Gilman, 170-71.

37. "John H.," in 924 Gilman, 171.

38. "John H.," in 924 Gilman, 171; "Charles L.," in 924 Gilman, 228; "Letter from Alex K. to Berkeley Zoning Board," in 924 Gilman, 337; Gina Arnold, Kiss This: Punk in the Present Tense (New York: St. Martin's Griffin, 1997), 122-29.

39. "John H.," in 924 Gilman, 172.

40. "John H.," in 924 Gilman, 172; A. Clay Thompson, "Seen But Not Heard," San Francisco Bay Guardian, January 6, 1999, in 924 Gilman, 320-21.

41. "John H.," in 924 Gilman, 172-33; "Chris S.," in 924 Gilman, 279; "Chris H.," in 924 Gilman, 216.

42. Alan Moore and Marc Miller, "The ABCs of ABC No Rio and its Times," in ABC No Rio Dinero; Committee for the Real Estate Show, "MANIFESTO or Statement of Intent," in ABC No Rio Dinero, 56; "Statement by the Organizers of the Real Estate Show," January 1980, http://abcnorio. org/about/history/ res statement 80.html (accessed September 2, 2007); Chris Oliver, "Heave-Ho Ends Sit-In on Eastside," New York Post, January 3, 1980, http://www.abcnorio.org/about/history/ post 80.html (accessed October 20, 2007); Josh Barbanel, "Artists Ejected in Occupation of a Storefront," New York Times, January 9, 1980, B2. Sarah Ferguson, "The Struggle for Space: 10 Years of Turf Battling on the Lower East Side," in Resistance: A Radical Political and Social History of the Lower East Side, ed. Clayton Patterson (New York: Seven Stories Press, 2007), 141-65; "Third Officer Charged in Tompkins Melee," New York Times, November 5, 1988, 30; Lisa W. Foderaro, "9 Held in Protest Near Tompkins Square Park," New York Times, April 2, 1989, 31; Jesus Rangel, "Protest in Tompkins Square Park Draws 300 Officers and 16 Arrests," New York Times, May 3, 1989, B2; John Kifner, "New York Closes Park to Homeless," New York Times, June 4, 1991, A1; Thomas Morgan, "New York City Bulldozes Squatters' Shantytowns," New York Times, October 16, 1991, A1.

43. Law, Enter the Nineties, 2-3,13; Chris Boarts-Larson, e-mail message to author, September 14, 2007; New York City Council, In the Matter of the Regularly Scheduled Meeting of the Permits, Dispositions, and Concessions Committee, November 14, 1995, http://abcnorio.org/about/history/ city council 1114 95.html (accessed October 20, 2007); Steven Wishnia, "ABC Community Center Fights for Survival," The Shadow, December 1995, http://www.abcnorio.org/about/history/ shadow 95.html (accessed October 20, 1997). Joe Austin calls this period an "all-out war...on the 


\section{Dawson Barrett}

homeless." Joe Austin, Taking the Train: How Graffiti Art Became an Urban Crisis in New York City (New York: Columbia University Press, 2001), 226.

44. Vivian S. Toy, "Differing Viewpoints on the Squatters Next Door," New York Times, May 31, 1995, B2; Shawn G. Kennedy, "Riot Police Remove 31 Squatters From Two East Village Buildings," New York Times, May 31, 1995, A1; David Stout, "The Tenement Battle Is Over, but Not the Fight," New York Times, July 6, 1995, B3.

45. Wishnia, "ABC Community Center Fights for Survival."

46. Claude Solnick, "ABC No Rio Fights Eviction By a Nonprofit," Manhattan Mirror, October 10, 1996, http://www.abcnorio.org/about/history/mm_10_95.html (accessed October 20, 2007).

47. New York City Council, November 14, 19995; Sarah Ferguson, “ABC No RIP," Village Voice, October 8, 1996, http://www.abcnorio.org/about/history/abc_no_rip.html (accessed October 20, 2007).

48. Solnick, "ABC No Rio Fights Eviction By a Nonprofit"; Steve Ellman, "Blame it on Rio," Time Out New York, October 10, 1996, http://www.abcnorio.org/about/history/tony_96.html (accessed October 20, 2007); Robin Goldsmith, letter to the editor, Time Out New York, October 26, 1997, http://www.abcnorio.org/about/history/rg_letter.html (accessed October 20, 2007).

49. Steven Wishnia, "Arts Center Fights Eviction," Tenant, February 1997, http://www.abcnorio. org/about/history/tenant 97.html (accessed October 20, 2007); Andrew Jacobs, "What a Difference Two Decades Makes," New York Times, January 12, 1997, CY4; Michael Haberman, "5 Arrested in ABC No Rio Protest," Villager, January 22, 1997, http://www.abcnorio.org/about/history/v 2297. html (accessed October 20, 2007); Andrew Jacobs, "Arts Group Wins Eviction Battle," New York Times, February 23, 1997, CY8.

50. Jacobs, "Arts Group Wins Eviction Battle"; Robert Kolker, "Spare Some Change?" Time Out New York, March 20, 1997, http://www.abcnorio.org/about/history/tony_3 97.html (accessed October 20,2007); Colin Moynihan, "For \$1, a Collective Mixing Art and Radical Politics Turns Itself Into Its Own Landlord," New York Times, July 4, 2006, B3; ABC No Rio, "ABC No Rio News: ABC NO RIO TO RECEIVE FUNDING FOR BUILDING PROJECT," June 26, 2009, http://www. abcnorio.org/about/news.html (accessed June 30, 2009); James Trimarco, “ABC No Rio," Brooklyn Rail, February 2008, http://www.brooklynrail.org/2008/02/local/abc-no-rio (accessed June 30, 2009).

51. ABC No Rio's decisions to work with the city and to re-locate squatters have not been without detractors. However, according to ABC No Rio Director Steven Englander, the collective's decisions were reached democratically, and squatters had been recruited for the explicit purpose of making eviction more difficult. The decision not to "go out on principle as martyrs" was not a difficult one. Says Englander, "thousands and thousands of people have benefited from [ABC No Rio's survival] . . . eight people lost where they were living, me being one of them." Liza Kirwin, "Oral history interview with Steven Englander," September 7-October 10, 2007, Archives of American Art, Smithsonian Institution, http://www.aaa.si.edu/collections/oralhistories/transcripts/englan07. htm (accessed July 14, 2010).

52. Most of these institutions have a web presence. See also: Stewart Varner, "Youth Claiming Space: The Case of Pittsburgh's Mr. Roboto Project," in Youth Cultures: Scenes, Subcultures, and Tribes, ed. Paul Hodkinson and Wolfgang Deicke (New York: Routledge, 2007), 161-74; Profane Existence, Making Punk a Threat Again: The Best Cuts, 1989-1993 (Minneapolis: Loin Cloth Press, 1997).

53. Solidarity Books Collective, "Patriot Acts in Indianapolis," Bloomington Alternative, August 17, 2003, http://www.bloomingtonalternative.com/articles/2003/08/17/7356 (accessed July 14, 2010); Tom Spalding, "Protest Group Angry over Police Search of Indianapolis Bookstore," Indianapolis Star, August 15, 2003, http://www.democraticunderground.com/discuss/duboard. php?az=view_all\&address=104x180761 (accessed July 14, 2010); John the Baker, "Burnt Ramen Closing," http://www.burntramen.com/ramenclosing.htm (accessed July 14, 2010); Nikolaj Viborg, dir., 69 (Hybrid Films, 2008). 